\title{
REGULATION OF PRICES FOR AGRICULTURAL PRODUCTS
}

\author{
Stepan Poperechny ${ }^{1}$, Oksana Salamin ${ }^{2}$ \\ ${ }^{1}$ Associate professor, Dr., Stepan Gzhytskyi National University of Veterinary Medicine and Biotechnologies Lviv. \\ Adress: 50, Pekarska street, 79010 Lviv, Ukraine. \\ Phone Number+380672533267, Email address stepany2008@ukr.net \\ ${ }^{2}$ Associate professor, Dr., Stepan Gzhytskyi National University of Veterinary Medicine and Biotechnologies Lviv. \\ Adress: 50, Pekarska street, 79010 Lviv, Ukraine. \\ Phone Number+380677111324, Email addressoksana_Salamin@i.ua
}

Received 1803 2020; Accepted 31082020

\begin{abstract}
The means of state regulation of procurement prices for agricultural products that were applied in Ukraine over the past years of reform, did not ensure the overcoming the price disparity and high price volatility. Due to the high price volatility, funds are not invested in areas of agriculture with a long payback period. Bank loans are not attracted to develop these industries. Given the current level and price ratio, direct government support does not have the proper stimulating effect on agricultural development. The purpose of the article is to analyze the means of state regulation of prices for agricultural products, their effectiveness, justification of the possibility and feasibility of pricing at self-regulatory organizations created by business entities. To achieve the goal, the following research methods were used: analytical method, abstract-logical method, graphical method. It has been suggested that state support of agriculture should be steered on the creation of self-regulatory organizations. Such organizations would form prices that are acceptable to market participants. The scope of direct market regulation would expand, the list of pricing tasks that need to be addressed by means of direct state regulatory influence would be reduced.
\end{abstract}

Keywords: modes of price regulation, price parity, price survey, price volatility, self-regulatory organizations, State regulation of prices.

JEL Codes: D40, E39, H19, L51, Q18.

\section{Introduction}

The price level is a determining factor in influencing the behavior of business entities, the pace and proportions of development of individual enterprises and industries, the fullness of use of agricultural resources, state food security, and the like. Other levers of regulatory influence just weaken or strengthen the defining price influence. The severity of issues that have not been resolved by automatically operating market levers, their recurrent exacerbation in individual agricultural markets are evidence of the practical significance and relevance of the research on approaches to determining the possible and appropriate impact on prices, forms and modes of price regulation.

The issues of agricultural product pricing and their regulation are subject of the work of many economists. The works of many scientists are devoted to the general theoretical and applied problems of pricing, pricing of certain types of agricultural products. Mckendree, Tonsor, Schroeder, Nathan P. Hendricks (2019) analyze the problems of price volatility and the delayed response of agricultural producers to changes in market conditions and retail prices.

Copyright (C) 2020. Published by Vytautas Magnus University. This is an open access article distributed under the terms of the Creative Commons Attribution Non-Commercial 4.0 (CC BY-NC 4.0) license, which permits unrestricted use, distribution, and reproduction in any medium provided the original author and source are credited. The material cannot be used for commercial purposes. 
The work suggests that government policies be focused on market research and forecasting, timely communication of market trends to product manufacturers. This would weaken the monopolistic influence of individual market participants on pricing. Tripathi (2019) believes that the development of state pricing policies is complicated. This complexity is due to the fact that the price performs multiplicity of functions and all the functions are problematic to be covered with a price policy. Moreover, in recent years, the state influence on pricing is being limited by the World Trade Organization. The central problem, which is within the field of view of most researchers and determines the watershed in conceptual approaches to price regulation, is price parity. The whole range of views is offered - from refusal to maintain price parity for agricultural and industrial products, to finding ways to ensure it. Demianenko (2004) considers upholding price parity as an example of neglecting objective market trends. Pasxaver, Moldavan, Shubravska, (2012), Shpychak (2012), Mykytyuk (2012), Suprun, Velychko, Ivanikova (2015) substantiate the need for state regulation of prices for agricultural products in Ukraine through an inadequate level of formation of the agricultural market infrastructure. Without such regulation, prices will be regulated not by the market, but by individual participants who have monopoly opportunities. Bodnar, Kozak, Kopytec (2014) offer discussion methods for maintaining price parity, which include, for example, removing intermediaries from product distribution channels. Semenda D. Semenda O. Petruk (2018) indicate that without state regulation of prices and support for price parity for agricultural and industrial products in Ukraine, even simple reproduction in agriculture is impossible. Rosoxa, Sharapa (2016) indicate that in Ukraine, for all the years of reform, a holistic concept of pricing has never been formed. The foreign experience of price regulation is analyzed. It is noted that price regulation is an element of the state agrarian policy and such regulation should be aimed at achieving general strategic goals.

Existing works have not established the generally accepted approaches to the feasibility, possibilities and ways of price regulation for agricultural products. Therefore, the purpose of our study is a comparative analysis of the ways of state regulation of prices for agricultural products, justification of appropriate methods of such regulation.

The object of research is the processes of formation and price regulation for agricultural products. The subject of the research is the methods of price regulation, the possibility of combining state price regulation with their regulation in self-regulatory organizational systems.

In the scientific research process, the following methods were applied: comparative-analytical - to compare the effectiveness of different methods of price regulation, abstract-logical - to study the possibility and necessity of price regulation in terms of market relations, formulation of conclusions and proposals, the graphical method - to illustrate the effects of inappropriate regulation of prices of milk for a general reduction in the number of cows in Ukraine and further milk shortages.

The result of the research can be used by state agricultural management bodies, advisory services and agricultural enterprises to form self-regulatory economic systems.

\section{Results and discussion}

In Ukraine, the state regulatory policy in the field of agricultural products pricing is aimed at monitoring, stabilizing and limiting the price increase for food staples and ensuring a return on advanced capital in agriculture, not lower than the average level for the state economy. It is problematic to ensure an increase in purchase prices for agricultural products and lower prices for 
food products. Information on the results of price monitoring by the State Statistics Service of Ukraine characterizes price trends in the food products retail sector, and only peripherally - in the agricultural sector. Prices are not forecasted, and information on existing prices is not transmitted to agricultural producers. Manufacturers are deprived of pricing information even in alternative distribution channels. They are not able to make informed decisions to adapt to the expected price level. The performance of market regulation functions is weakening. The problems of adaptation to the level and price ratio are characteristic primarily for small business entities which do not have their own own market research services. In addition, unlike large enterprises, small enterprises cannot form their own distribution channels. This leads to increased exposure to local procurement structures that monopolize the market. Combined with the influence of objective market factors, price volatility intensifies to a level at which it is impossible to develop not only strategic, but even current economic plans, or to attract bank loans for their implementation. This problem is the main constraint on the development of agricultural sectors with a long production time and a slow payback period.

The restriction by state authorities of raising retail prices for food products with the aim of social protection of low-income and low-paid citizens carries out a negative impact on the general state of agriculture. Such a restriction can only be a temporary solution for social protection of the population. Its long-term appliance, combined with the monopolistic tendencies of business entities in the field of procurement and processing of products leads to a significant reduction of procurement prices and a corresponding decrease in the volume of production in agriculture. The reduction in the supply of commodity weights objectively leads to another price increase at all levels of the product distribution network, coupled with increased unemployment due to the underutilization of resources and intensified social problems. An illustration of this serves a limitation of the profitability of socially significant dairy products production in 2009 in order to counter the negative results of the general financial crisis. The methodology for determining the feasibility and validity of price increase for such goods in the context of high inflation of that period provided for the product costing based on standard costs and planned production volumes, as well as an acceptable level of profitability, the maximum level of which could not exceed $21 \%$. As a matter of fact, the costly pricing concept had been applied. The differences from conventional approaches to planned pricing consisted only in determining not a single target price for all manufacturers, but individual price for each. This reinforced subjectivness in determining the price in the process of declaring and obtaining permission to change it; narrowed the possibility of price maneuvering in accordance with the market conditions for dairy products and raw materials, adaptation to inflationary processes, and directing the pricing policy of dairy plants to achieve competitive advantages, including in the field of raw materials procurement. Dairy plants were forced to reduce the procurement price of milk. In 2009, they have been forming prices at a lower level than in the previous year (Fig. 1). 


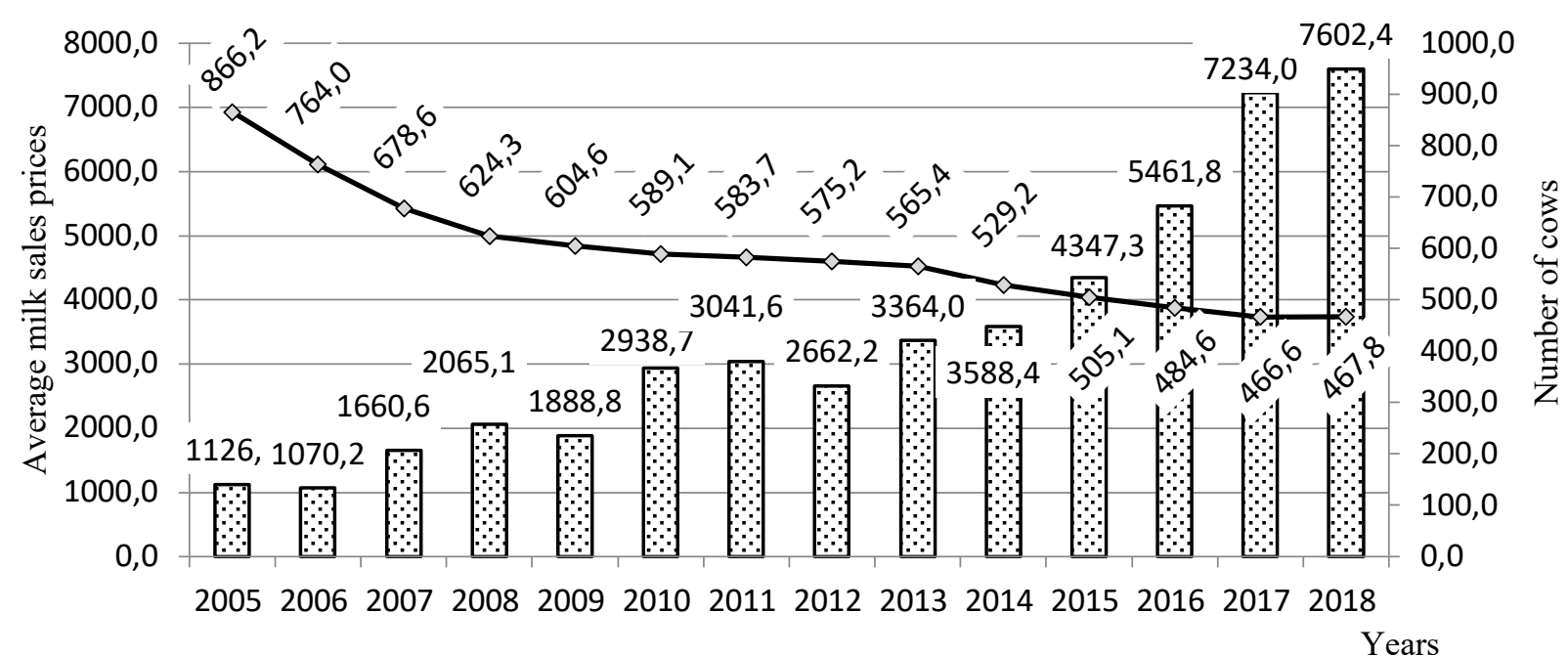

$\because$ Average milk sales prices, hrn per tona

$\neg$ Number of cows at the end of the year, thousands of heads

Fig. 1. Average prices of milk farms and number of cows in Ukraine

Source: Statistical Yearbook Agriculture of Ukraine for 2009 (2010) and for 2018 (2019)

The number of cows decreased. The Ministry of Agrarian Policy and Food of Ukraine was considering the compelled critical import of butter and milk powder.

Dairy plants did not apply in practice the government-mandated minimum procurement prices for milk. The increase in procurement prices to the defined minimum level led to a loss of competitiveness of dairy products in foreign markets and the competitive positions of domestic dairy plants in the local market. Many dairy plants have abandoned the procurement of raw materials, which led to a decrease in demand for it, and an increase in the monopolization of the milk procurement market. In 2006 and 2012, when the minimum acceptable milk price levels were approved, the average level of procurement prices decreased compared to prices of previous years (Fig. 1).

Currently, the most common way of state regulation of prices for agricultural products in Ukraine is the commodity and financial interventions by the government. By purchasing products to replenish government reserves or by selling them from these reserves affects the supply and demand, and therefore prices. However, the volumes of such operations are insignificant and do not have a significant impact on the level and stabilization of prices.

A well-formed prices liberalization in the conditions of market relations is currently combined with the need to harmonize domestic regulatory acts with those applied in the EU and to comply with obligations under multilateral agreements concluded when Ukraine become the WTO member. By the provisions of the WTO, government intervention in pricing processes is limited as one distorting market results. As international experience shows, the prerequisite for refusing state intervention in the pricing processes in the agricultural sector is overproduction of agricultural products, increased competition in foreign markets and the inappropriateness of pricing that would stimulate the surplus production. Production losses resulting from reduced production volumes are in such cases offset by direct taxpayer support. Such a policy can be applied in economically developed countries, where it is possible to allocate the necessary funds from the state budget. The painlessness of this process in the USA, for example, is explained by the fact that the majority of farmers here receive basic income 
not from agriculture. In Ukraine, such a policy would not lead to a reduction in absolute overproduction, but to an increase in food security problems.

The market volatility and price control by regulating the natural reaction of manufacturers to objective market processes can be no argument against price regulation. Market volatility is the result not so much of the influence of objective market factors as of the subjective intervention of individual monopolistic structures. With the existing ratio of prices for industrial and agricultural products, the effectiveness of other levers of state regulatory influence decreases. Subsidies to agriculture, soft loans, tax benefits through prices flow to the areas adjacent to agriculture, without eliminating the problems of agriculture they aimed at addressing.

High price volatility destroys the agricultural sector. First of all, in leading economically developed countries, provided even less pronounced, but similar conditions, the policy of price parity was never abandoned. Secondly, in all these countries, state price regulation was combined with the establishment of self-regulatory organizations and efforts of manufacturers to prevent the monopolistic influence of individual business entities on price. The overall coordination of the activities of business entities, including pricing, is carried out in these countries by public organizations - foundations created according to product principles, trade unions and the like. Also, often representatives of wage labor are members of such organizations, which makes for the social orientation of concerted action. Provided that an agreed price level is reached, determined by these public organizations, a minimum intervention of state bodies in pricing processes is required.

Warnings about the mandatory state influence on the price, without which the monopoly companies would never voluntarily refuse it, are groundless. The need of increasing procurement prices, for example, of milk to overcome the trend of decreasing the number of cows, is also obvious for dairy plants holding a monopoly position. For them, this would solve the problem of the procurement of raw materials, a fuller use of capacities, the strengthening of competitive positions, and for many- avoiding bankruptcy. The requirement to immediately increase the procurement price is unacceptable. Due to the high capital intensity of dairy cattle breeding and the long payback period in the face of high price volatility, milk manufacturers do not respond to prices instant increase. The concerted actions of all business entities united by a common chain of the commodity weights movement are acceptable. The experience of creating such self-regulatory organizations was known even in the former Soviet Union. In the second half of the 1970s, integrated agro-industrial structures of various organizational forms were developed here in order to harmonize the economic interests of business entities. Their appropriateness in conditions of command and plan pricing and similar determination of sales revenue looks currently perplexing. Integrated systems covering the areas of production and products processing are particularly necessary in the context of market relations. Government incentives to benefit creation of such organizations and their concerted actions can be carried out through the formation of public-private partnerships, in which the agreements on price levels would be supplemented by direct state support for increasing the number of cows, the use of technologies for the production of raw materials suitable for the manufacture of dairy products competitive in foreign markets.

Historically, the first organizational form of opposing agricultural producers to monopolistic trends in the procurement of products were sales cooperatives. They emerged in the late 19th century at the initial stages of the manifestation of monopoly approaches in the field of pricing. The main advantage of such cooperatives is the formation of homogeneous products consignments by small commodity producers, sufficient to be brought to distant markets, bypassing local purchasing 
organizations that monopolized the market. Organizational efforts of the agricultural management bodies and state support in Ukraine did not provide a significant impact on the formation of cooperative distribution channels. Most of the cooperatives established formally operate. The determining factor in their creation was state support, not an attempt by the cooperative members to realize their interests by forming higher prices for manufactured products compared to the existing ones. Numerous recommendations on the feasibility of establishing service cooperatives in Ukraine are justified by the advantages of joint implementation of agricultural work, by the provision of necessary services by cooperatives. Recommendations on joint processing of products and trade to avoid monopoly influence and the formation of reasonable prices are scarcely met. Created cooperatives quite often sold the products to the same purchasing organizations, at the same monopoly prices at which individual producers sold their products prior to membership in the cooperative. This is the main reason for the short functioning of cooperatives. At the same time, informal associations that arise as a result of joint lease by small vehicle manufacturers for the joint sale of products, are common in Ukraine. Government support for such structures is stepping up the process of creating formal, viable marketing cooperatives.

A necessary condition for market price generation is the formation of the agricultural market infrastructure, creation of conditions for manufacturers to choose distribution channels on an alternative basis, and the organization of auctions. The dissemination of information on the results of auctioning in wholesale agricultural markets for example, would affect prices that are formed in other distribution channels.

The strategic direction of state influence on pricing is to stimulate the development of a competitive market environment. Improving the market organizational structure expands the scope of automatic market regulation, provides the necessary pace and proportions of development of industries in cooperative and integrated systems, reduces the number of pricing tasks that must be solved by means of state regulatory influence.

\section{Conclusions}

The contentious issues of the need, opportunities, and an acceptable level of state influence on pricing in the agricultural sector of the Ukrainian economy can be solved by creating selfregulatory organizations. Even business entities that occupy monopoly positions in the market, but do not provide adequate profitability due to the shortage of raw materials are interested in their creation. The strategic direction of state influence on agricultural pricing is the formation of the agricultural market infrastructure, facilitating auctions, market research and forecasting, information communication to all business entities. This broadens the scope of automatic market regulation of prices and reduces the need to maintain price parity by means of direct government influence.

\section{References}

Andrijchuk, V. G. (2005). The effectiveness of agricultural enterprises: the theory, methodology, analysis. Kyiv: Kyivs'kyj natsional'nyj ekonomichnyj universytet ( in Ukr.).

Ashutosh K. Tripathi (2019). Agricultural Price Policy, Output, and Farm Profitability-Examining Linkages during Post-Reform Period in India. Asian Journal of Agriculture and Development. Vol. 10. No. 1:91110.

Bodnar, O. V., Kozak, O. A., Kopytec, N. H. (2014). The directions of regulation of relations between producers, traders and consumers of socially important food. Ekonomika APK (Economy of AIC). No. 2: 42-50 (in 
Ukr.).

Dem'yanenko, S. I. (2004). What agricultural policies need Ukraine? Dzerkalo tyzhnya (Mirror of the week), 17 Retrieved from http://gazeta.dt.ua/ECONOMICS/yaka_agrarna_politika_potribna_ukrayini.html

Kovalenko, O. V., Slavov, V. P., Shubenko, O. I. (2013). Formation market price of milk processing products. Ekonomika APK (Economy of AIC). No.7:22-28 (in Ukr.).

Kvasha, S. M. (2001). Directions of improve the mechanisms formation of market equilibrium on agricultural markets. Ekonomika APK (Economy of AIC). No. 2:161-167. ( in Ukr.).

Lukinov, I. I. (2004). Methods and tools of state regulation of economies in transition. Ekonomika Ukrayiny (Economy of Ukraine). No. 5:7-11.( in Ukr.).

Melissa G.S. Mckendree, Glynn T. Tonsor, Ted C. Schroeder, Nathan P. Hendricks. (2019). Impacts of Retail and Export Demand on United States Cattle Producers. American Journal of Agricultural Economics.https://academic.oup.com/ajae/advance-article-abstract/doi/10.1093/

ajae/aaz034/5554804

[26.08.2019]

Mykytyuk, V. M. (2012). Market fundementalizm and state regulation in the field of animal husbandry. Ekonomika APK (Economy of AIC). No.10:57-62. ( in Ukr.).

Pasxaver, B. J., Moldavan, L. V., Shubravska, O. V. (2012) The main problems of agricultural production. Ekonomika APK (Economy of AIC). No. 9: 3-9. (in Ukr.).

Rossokha V.V., Sharapa O.M. (2016). Institutional support of management of economic activity of agriculturalenterprises. Economica APK (Economy of AIC). No.10:73-82. (in Ukr).

Semenda D.K., Semenda O.V., Petruk T.Y. (2018). Economical aspects of agricultural enterprises functioning. Economica APK (Economy of AIC). No. 10:106-116. (in Ukr). DOI: https://doi.org/10.32317/22211055.201810106 .

Shpychak, O. M. (2012). Theoretical aspects of pricing for agricultural products. Ekonomika APK (Economy of AIC). No.8:3-10. ( in Ukr.).

Statistical Yearbook Agriculture of Ukraine for 2009 (2010). Retrieved from http://www.ukrstat.gov.ua/.

Statistical Yearbook Agriculture of Ukraine for 2018 (2019). Retrieved from http://www.ukrstat.gov.ua/.

Suprun, O. M., Velychko, Ye. I., Ivanikova, I. S.(2015). Influence of price factors on the milk production in agricultural enterprises. Ekonomika APK (Economy of AIC). No. 12:64-67. ( in Ukr.). 